\title{
Teamwork in a Coronary Care Unit: facilitating and hindering aspects*
}

\author{
Trabalho em equipe em Unidade Coronariana: facilidades e dificuldades \\ Trabajo en equipo en Unidad Coronaria: facilidades y dificultades
}

Bethania Ferreira Goulart ${ }^{1,2}$, Silvia Helena Henriques Camelo ${ }^{3}$, Ana Lúcia de Assis Simões ${ }^{4}$, Lucieli Dias Pedreschi Chaves ${ }^{5}$

\section{How to cite this article:}

Goulart BF, Camelo SHH, Simões ALA, Chaves LDP. Teamwork in a coronary care unit: facilitating and hindering aspects. Rev Esc Enferm USP. 2016;50(3): 479-486. DOI: http://dx.doi.org/10.1590/S0080-623420160000400015

* Extracted from the thesis "Aspectos facilitadores e dificultadores do trabalho em equipe em Unidade de Alta Densidade Tecnológica”, Universidade de São Paulo, Escola de Enfermagem de Ribeirão Preto, 2015.

${ }^{1}$ Universidade Federal do Triângulo Mineiro, Departamento Didático-Científico de Enfermagem em Educação e Saúde Comunitária, Uberaba, MG, Brazil.

${ }^{2}$ Universidade de São Paulo, Escola de Enfermagem de Ribeirão Preto, Programa Interunidades, Ribeirão Preto, SP, Brazil.

${ }^{3}$ Universidade de São Paulo, Escola de Enfermagem de Ribeirão Preto, Ribeirão Preto, SP, Brazil.

${ }^{4}$ Universidade Federal do Triângulo Mineiro, Programa de Pós-Graduação, Uberaba, MG, Brazil.

${ }^{5}$ Universidade de São Paulo, Escola de Enfermagem de Ribeirão Preto, Departamento de Enfermagem Geral e Especializada, Ribeirão Preto, SP, Brazil.

\section{ABSTRACT}

Objective: To identify, within a multidisciplinary team, the facilitating and hindering aspects for teamwork in a coronary care unit. Method: A descriptive study, with qualitative and quantitative data, was carried out in the coronary care unit of a public hospital. The study population consisted of professionals working in the unit for at least one year. Those who were on leave or who were not located were excluded. The critical incident technique was used for data collection, by means of semi-structured interviews. For data analysis, content analysis and the critical incident technique were applied. Results: Participants were 45 professionals: 29 nursing professionals; 11 physicians; 4 physical therapists; and 1 psychologist. A total of 49 situations ( $77.6 \%$ with negative references); 385 behaviors (54.2\% with positive references); and 182 consequences emerged ( $71.9 \%$ with negative references). Positive references facilitate teamwork, whereas negative references hinder it. A collaborative/communicative interprofessional relationship was evidenced as a facilitator; whereas poor collaboration among agents/inadequate management was a hindering aspect. Conclusion: Despite the prevalence of negative situations and consequences, the emphasis on positive behaviors reveals the efforts the agents make in order to overcome obstacles and carry out teamwork.

\section{DESCRIPTORS}

Patient Care Team; Interprofessional Relations; Hospitals; Nursing, Team. 


\section{INTRODUCTION}

There is a close link among the health care model, the health service organization model, and teamwork. The clinical care model determines the health professional training, and the service organization model is anchored by the functional method ${ }^{(1-2)}$.

Work organization based on the capitalist division of labor ${ }^{(1)}$ leads to a technical aspect, and to a social division as well. This context does not strengthen the implementation of teamwork, since it does not presuppose integration and sharing of knowledge and actions carried out by different professionals, generating misunderstandings among team agents. In order to overcome that, emphasis must be given to multidisciplinarity and reasoned on knowledge and practice integration approach.

Teamwork is understood as having a common/single goal, collectively attained through the contribution of all components. It allows the consolidation of teams, emphasizing that unity among their members and a trust-based relationship and respect are contributing factors for such consolidation to take place ${ }^{(2-3)}$.

Teamwork requires more than gathering different professionals in the same working environment ${ }^{(2)}$; and, therefore, it must have effective collaboration and communication among the team agents, knowledge exchange, and complementarity of actions. It is important to emphasize that interprofessional collaboration contributes to improving the quality of patient care ${ }^{(4)}$.

Addressing this topic, the contributions related to the proposal of concept and typology of teams, integration, and grouping stand out. Teamwork is considered to represent a collective working modality created through integration between technical interventions and the interactions among agents $^{(5)}$.

This research, based on identified studies ${ }^{(2,5-6)}$, considers the teamwork concept as a strategy and a tool for organizing healthcare work in the perspective of coordination and integration, with joint responsibility of different professionals, collectively building and implementing common goals, thus also allowing professionals to overcome obstacles in everyday work. Teamwork presupposes relationships that promote collaboration and communication that go beyond the personal level, with an aim at mutual assistance in developing work, based on dialogical and horizontal relationships.

Teamwork represents a tool with a potential to promote integrated/coordinated working practice in high technological density units, and to meet the actual demands of health care users more coherently, with a view to overcoming the everyday practice based on a fragmented and biological approach, divided by procedures and tasks aimed at illnesses and not toward subjects. In this sense, these characteristics could be understood as adequate for coronary care units (CCUs), where the demand specifications for patients, employed personnel, technological resources involved, and the sector physical space, jointly coordinated, require effective professional interaction for comprehensive care to its users.
The CCU is a sector projected for the critical care that relies on a physical area, material resources, high tech density equipment, and multidisciplinary team aimed at assisting patients with acute coronary syndrome. However, this context does not necessarily assure that the work can be carried out in the modality of a team. In order to provide adequate care to patients, the coordination and/or integration of several professional categories is proposed, providing support for accomplishing the work in the context of comprehensive care and overcoming the fragmented logic and division of labor. The identification of factors that facilitate or hinder teamwork in the CCU could contribute for the implementation of actions that allow its accomplishment. Up to this date, such aspects were not identified in this scenario. Thus, the objective of this study was to identify, along with a CCU multiprofessional team, aspects that facilitate and hinder teamwork.

\section{METHOD}

A descriptive study, applying qualitative and quantitative data, was conducted in the CCU of a public tertiary teaching hospital, with 291 beds available, in the city of Uberaba, in the state of Minas Gerais. This hospital is considered a reference for high tech density care.

The critical incident technique (CIT) was used for collecting direct observations of human behavior in specific situations ${ }^{(7)}$, which contributes for surveying conceptions, perceptions, and attitudes related to the research subject ${ }^{(8)}$. Critical incidents (CIs) must necessarily include these situations, the behavior of professionals dealing with them, and the consequences stemming from them ${ }^{(9)}$.

The theoretical framework was based on the concepts of the healthcare working process ${ }^{(10)}$, since its elements (subject, purpose, tools, and agents) are essential for anchoring and analyzing the results related to the healthcare teamwork dynamics.

The CCU of the studied hospital is a critical unit with 10 beds for assisting patients with acute coronary syndrome. It relies on specific material and technological resources for providing services in cardiology. The unit team consists of 68 professionals, namely 17 physicians; 10 nurses; 1 nursing coordinator that takes direct technical responsibility for the $\mathrm{CCU}$ and the general adult intensive care unit; 33 nursing technicians/aides; and 4 physical therapists. In addition, 1 psychologist, 1 nutritionist, and 1 social assistant are part of the unit staff; however, they do not stay exclusively in the sector, since they also belong to other departments. In each shift, the team consists of: two physicians, one nurse, six nursing technicians/aides, and one physical therapist. The current flowchart, at the time of data collection, showed a hierarchical and vertical approach.

Of a total of 68 professionals in the healthcare team, we selected for participation whose who met the inclusion criterion, namely working at the unit for at least one year. Those who were on leave at the time of data collection, who refused to participate, and those who were not located after three attempts for scheduling the interview were all excluded. Therefore, the final sample consisted of 45 professionals (66.2\%), distributed in 20 nursing technicians/ 
aides (44.5\%), 11 physicians (24.4\%), 9 nurses - including the general adult intensive care unit and CCU nursing coordinator (20.0\%), 4 physical therapists (8.9\%), and 1 psychologist (2.2\%).

Twenty-three professionals did not participate; of whom 14 were excluded (eight nursing technicians/aides, two nurses, two physicians, one nutritionist, and one social assistant) for not meeting the inclusion criterion. Nine professionals (five nursing technicians/aides and four physicians) refused to participate, claiming lack of time and/or difficulty/embarrassment for answering the interviews.

Data were collected through semi-structured interviews guided by a script, which was previously submitted for face and content validation by three experts on the topic and on research methodology. Later, a pilot test was conducted with five professionals who would be on vacation at the time of the final data collection.

For the final data collection, an interview was carried out by the researcher, face to face, and digitally recorded, on a date and place previously scheduled, in common agreement among the participants, the person responsible for the service and the researcher, in an environment that safeguarded privacy. The data were collected in January 2014. In order to assure confidentiality and privacy, the participants were identified as E1, E2, E3, and so forth, up to E45, where the letter $\mathrm{E}$ represents the participant interview, and the number the sequence of the interview, disregarding professional categories, since the interest of the study is focused on the team as a whole.

For data analysis, the interviews were transcribed by a specific professional, qualified for the purposes of this study, and the texts were verified one-by-one by the researcher.
After comprehensive reading of the interviews by the researcher, the CIs were extracted and separated into situations, behaviors, and consequences, thus composing the triad that characterizes the CI. Taking into account the reports observed and/or experienced by the participants, they received a positive or negative attribution, which was taken as factors that facilitate or hinder teamwork, respectively. For the CI analysis, descriptive statistics were initially used, which contributed to data description and overview ${ }^{(11)}$, in order to quantify the situations, behaviors, and consequences. Later, the reports related to each situation, behavior, and consequence were analyzed through content analysis ${ }^{(12)}$, applying the steps proposed by Dela Coleta ${ }^{(9)}$. Data analysis was conducted according to the theoretical framework adopted and the study object. This study was approved by the Research Ethics Committee of EERP-USP as per protocol CAAE 19822813.1.0000.5393. The study participants signed a free and informed consent form.

\section{RESULTS}

The results are showed through the identification of reported CIs, highlighting the situations, behaviors, and consequences regarding the heath care teamwork, in the setting in question. It is important to emphasize that the reports that took place in situations that were neither experienced nor observed were not considered, representing mere opinions, general accounts, and not CIs.

The 45 interviews carried out resulted in 49 situations that showed CI, involving 385 behaviors, and 182 consequences. The 49 situations identified in the $\mathrm{CI}$ analysis were grouped into three categories as content-related (Table 1).

Table 1 - Distribution of the categories of positive and negative situations relating to health care teamwork, extracted from the critical incidents reported by professionals in the coronary care unit of a public hospital - Uberaba, MG, Brazil, 2014.

\begin{tabular}{lcccccc}
\hline \multirow{2}{*}{ Situation categories } & \multicolumn{2}{c}{ Positive } & \multicolumn{2}{c}{ Negative } & \multicolumn{2}{c}{ Total } \\
\cline { 2 - 7 } & $\mathbf{n}$ & $\mathbf{\%}$ & $\mathbf{n}$ & $\mathbf{\%}$ & $\mathbf{N}$ & $\mathbf{\%}$ \\
\hline Collaboration among agents & 8 & 16.3 & 16 & 32.6 & 24 & 48.9 \\
Care to patient & 3 & 6.1 & 11 & 22.5 & 14 & 28.6 \\
Management of agents & 0 & 0 & 11 & 22.5 & 11 & 22.5 \\
\hline Total & $\mathbf{1 1}$ & $\mathbf{2 2 . 4}$ & $\mathbf{3 8}$ & $\mathbf{7 7 . 6}$ & $\mathbf{4 9}$ & $\mathbf{1 0 0 . 0}$ \\
\hline
\end{tabular}

Most situations had a negative reference (77.6\%), viewed as factors that hinder teamwork.

The Collaboration among agents category encompasses mainly situations related to the collaboration among professionals in assisting the patients, in the context of mutual help and the communication and valorization of information provided by another colleague on a clinical case and therapeutic conduct. It has the greatest number of negative situations $(32.6 \%)$, as evidenced by the following comments:

(...) the nurse does not provide assistance to the technician the way it should (...) I did my part all by myself, because my colleague went to take care of her own patient (...) there were two patients for each one (...) I did not get any help (...) she left me alone! (E32).
(...) vasoactive drug, the doctor discontinued the drug. Then, he does not communicate, not even to the nurse, not even to the technician who is taking care of the patient and turns it off, discontinues, just stops the pump, and this already happened, stopped the pump and did not say a word (E47).

Management of agents stands out for containing negative references $(22.5 \%)$ only. It covers situations related to an insufficient amount of professionals, as a result of nonjustified absence; inadequate staff sizing and distribution; low commitment by the professional to work and feeling of professional depreciation, as identified in the following comments:

(...) Just yesterday we had only four workers, and we were already dealing with five, which it is not allowed, because it is 
supposed to have six, two for each isolation room, and we are just five. And yesterday we were just four, I was the one who had to stay alone (...) (E4).

I had " $X$ disease" a short while ago (...) they called me to say: you are coming back on the $2^{\text {nd }}$, and on the $3^{\text {rd }}$ you are on duty,
12 hours'. (...) They don't even ask how you are. (...) I did not get any phone call, I stayed 30 days on leave and did not get any, only from my colleagues, but not from my manager (E15).

The 385 behaviors were grouped as content-related into three categories (Table 2), according to the theoretical framework adopted for this study.

Table 2 - Distribution of the categories of positive and negative behaviors relating to healthcare teamwork, extracted from the critical incidents reported by professionals in the coronary care unit of a public hospital - Uberaba, MG, Brazil, 2014.

\begin{tabular}{lcccccc}
\hline \multirow{2}{*}{ Behavior categories } & \multicolumn{2}{c}{ Positive } & \multicolumn{2}{c}{ Negative } & \multicolumn{2}{c}{ Total } \\
\cline { 2 - 7 } & $\mathbf{n}$ & $\mathbf{0}$ & $\mathbf{n}$ & $\mathbf{\%}$ & $\mathbf{N}$ & $\mathbf{\%}$ \\
\hline Relating to other agents & 113 & 29.3 & 105 & 27.3 & 218 & 56.6 \\
Delivering care to patients & 79 & 20.5 & 42 & 10.9 & 121 & 31.4 \\
Managing agents & 17 & 4.4 & 29 & 7.6 & 46 & 12.0 \\
\hline Total & $\mathbf{2 0 9}$ & $\mathbf{5 4 . 2}$ & $\mathbf{1 7 6}$ & $\mathbf{4 5 . 8}$ & $\mathbf{3 8 5}$ & $\mathbf{1 0 0 . 0}$ \\
\hline
\end{tabular}

The 385 reported behaviors indicate that each situation described could involve several actions carried out and expressed by the professionals. The predominance of positive behaviors (54.2\%) stands out, concentrating mainly in the Relating to other agents $(29.3 \%)$ category, as illustrated in the following statements:

I communicated to the nursing technician and to the nurse who was on duty that they should be careful with the manipulations (...) so he (patient) could feel less agitated as possible (E10).

(...) I had to take care of four patients in there (...) the nurse belped me, we worked together (E16).

Despite the predominance of positive references, the concentration of negative references (7.6\%) in Managing agents draws attention, involving behaviors towards absenteeism, inadequate staff sizing and distribution, lack of commitment to work and disrespect with hierarchy, as illustrated in the following comments:

(...) you ask 'why did you give the weekend off to that person?' '(...) because she did not ask for it.'(E15).

(...) there is an employee who misses work a lot! (...) you are counting on him for the shift (...) he calls at noon... and does not come (...) (E29).

The 182 consequences, identified as the result of situations relating to the work dynamics in a multiprofessional team, were grouped as content-related into two categories (Table 3).

Table 3 - Distribution of the categories of positive and negative consequences relating to healthcare teamwork, extracted from the critical incidents reported by professionals in the coronary care unit from a public hospital - Uberaba, MG, Brazil, 2014.

\begin{tabular}{lcccccc}
\hline \multirow{2}{*}{ Consequence categories } & \multicolumn{2}{c}{ Positive } & \multicolumn{2}{c}{ Negative } & \multicolumn{2}{c}{ Total } \\
\cline { 2 - 7 } & $\mathbf{n}$ & $\mathbf{\%}$ & $\mathbf{n}$ & $\mathbf{\%}$ & $\mathbf{N}$ & $\mathbf{\%}$ \\
\hline Consequences for the professional/team & 32 & 17.6 & 92 & 50.5 & 124 & 68.1 \\
Consequences for the patient & 19 & 10.5 & 39 & 21.4 & 58 & 31.9 \\
\hline Total & $\mathbf{5 1}$ & $\mathbf{2 8 . 1}$ & $\mathbf{1 3 1}$ & $\mathbf{7 1 . 9}$ & $\mathbf{1 8 2}$ & $\mathbf{1 0 0 . 0}$ \\
\hline
\end{tabular}

The consequences resulting from situations related to the work dynamics in a multiprofessional team are predominantly negative (71.9\%), and are concentrated in the Consequences for the professional/team (50.5\%) category, consisting mainly of consequences related to professional dissatisfaction, as the following comments illustrate:

(...) I felt a bit embarrassed for going after him again just to ask (...) it is something for him, who is a doctor, that's it (E10).

\section{(...) you feel underestimated, you feel belittled, low (E15).}

In the Consequences for the patient category, the reports show comments regarding the quality of the care provided, as well as the recovery. Negative references (21.4\%) predominate, illustrated in the following statements:

(...) spent the entire night with subcutaneous emphysema without being drained, without being evaluated, no change in the medical parameters (E10).
(...) the patient ends up without the best assistance (E10).

(...) the patient ends up injured. He should have a better service (...) it was inadequate (E32).

Although the consequences for the patient showed a lower amount of reports, it is important to point it out, since it is one of the main objectives of healthcare teamwork regarding the delivery of adequate, comprehensive, and quality care. It is worth highlighting that the work dynamics in health care lead to consequences for the patients as well.

\section{DISCUSSION}

A given situation has an impact on the behaviors and consequences that yielded to positive and/or negative references, according to the perspective of those who experienced or observed the fact. The same behavior/consequence can be seen as positive by one participant and as negative by 
another, according to each one's perception.

Collaboration turned out as an important result both in situations and in behaviors. Collaborative practices stand out as one of the assumptions for carrying out joint work $^{(13-14)}$, promoting and enabling teamwork through integration of agents, knowledge, and actions ${ }^{(13)}$. In the context of sharing, collaboration and teamwork favor quality care to patients ${ }^{(15-16)}$.

Contrary to what was proposed by the authors, the results indicated situations of collaboration in a context of little mutual assistance and limited joint work, elements that hinder multiprofessional teamwork.

Such results are consistent with those of other authors, who claim that there are teams carrying out work in an individual and fragmented format. This may be due to the hierarchy among professions and medical hegemony ${ }^{(17-18)}$, which compromises cooperation and communication among agents, integrated work, and teamwork ${ }^{(13,17,19)}$.

This lack of coordination among professionals, among other factors, may reflect the absence of a formal structure that promotes systematic interaction among them ${ }^{(17)}$, the construction of fragile and uncooperative relationships among them; the process of professional training that can make interaction and collaboration difficult ${ }^{(2,20)}$ while establishing very strict hierarchical limits among different professions ${ }^{(17)}$.

Despite the higher amount of situations with negative references found in the Collaboration among agents category, Management of agents calls the attention for also having only negative references. If management of agents involved dealing with personnel all the time, a question arises: Why did it not get any positive reference? It leaves a question on the understanding of this $\mathrm{CCU}$ on the role performed by professionals, management, and its effects on teamwork.

It is important to highlight the centrality of agents in the working process, since the results show a category of situations and another category of behaviors related to the management of agents. It is worthy to clarify that the management of agents situation is related to a fact, either experienced or observed, that generates behaviors on the people involved and subsequent consequences; in other words, it is a trigger. On the other hand, behaviors refer to attitudes taken when facing a given fact. Thus, drawing from the findings, it is possible to say that the agents play a double role, both relevant, namely one related to the cause and the other reacting to actions; thus stressing the importance of agents in the teamwork context.

Problems related to the management of agents, revealed in the results shown by the authors, may be substantiated by the hierarchical models that still predominate in hospitals, based on verticalization, power centralization, control, and individual actions, which hinder collaborative practice and teamwork, compromising the care provided ${ }^{(1-3,13,18-19,21)}$.

Based on the above consideration, in this study, situations that hinder teamwork prevailed. It should be stressed that for each situation there are reactions, actions/behaviors related to it. Despite the concentration of negative references, the behaviors that enable teamwork in health care predominated, and the most frequent ones were in the Relating to other agents category.

However, it appears that there is an important contradiction revealed in the predominance of situations with negative references for Collaboration among agents and the predominance of behaviors with positive references in the Relating to other agents category. This indicates that some professionals developed actions with positive references in an attempt to overcome negative situations, aiming at developing joint work, and revealing a personal investment and effort in behalf of some agents.

The Relating to other agents category highlights positive references resulting from the use of non-material tools in the working process, linked to related aspects, such as collaboration and communication/exchange of information among agents. It can be deduced that in this case there is a conception that, in order to work in health care, it is crucial to engage in an adequate relationship with other professionals.

It is important to emphasize that an appropriate relationship with other agents has an impact on the care provided to patients and must be anchored on professional dialogical interactions that promote cooperative, collaborative, and exchange attitudes, aiming at integrating knowledge and practices. Interpersonal relationships have an influence on the work carried out and go beyond respectful social relations. The possibility of interaction among different agents is identified as a facilitating aspect that the work provides ${ }^{(2,5,22-23)}$.

Teamwork is driven by adequate interpersonal relationships, based on communication, coordination, respect, and use of the experience provided by the team members. Efficient communication, sharing of information, clarity of the professional functions, and shared values are crucial aspects for developing interprofessional practices ${ }^{(24-25)}$.

In this context, the results from the referred category are in line with the authors' assumptions, when it shows that working in health care demands interactions among different professionals, and may be substantiated, among other things, through collaborative/cooperation practice. Team integration presupposes active professional adherence supported by the care and contribution provided by colleagues that go beyond the minimum duties carried out at work $^{(17,20)}$. Collaborative practices facilitate teamwork, favoring the improvement of professional interaction and health care ${ }^{(13,22)}$.

Regarding communication, which also appears as a positive reference behavior in the Relating to other agents category, the literature indicates that it allows exchange of information among the team components ${ }^{(26)}$, facilitating comprehensive care and improved quality ${ }^{(21,27)}$ while promoting collaborative work and integration of distinct knowledge $\mathrm{e}^{(14)}$. Shared communication is a crucial tool for interprofessional collaboration, which facilitates teamwork $^{(4,14)}$ and contributes to enable coherent care to the patients' demands ${ }^{(14,21,27)}$. In this sense, sharing information among professionals and the development of collaborative behaviors among them are encouraged ${ }^{(28)}$. 
In this study, behaviors that facilitate teamwork predominated, particularly those in the Relating to other agents category, in the collaboration and communication context.

The fact that the results did not indicate the definition of common and shared objectives as an element for teamwork is noteworthy. Such element is sought as one of the aspects for team integration ${ }^{(5)}$, listed as one of the foundations for teamwork for other authors as well ${ }^{(2,29)}$. However, the results do not agree with the authors' proposal.

It is difficult to define whether the team in this CCU follows the logic of team integration or grouping modality. It is assumed that it embodies both characteristics; however, the grouping team element predominates, considering the prevalence of low collaboration, poor coordination between actions and performances, and isolated and fragmented performances, which lead to professional dissatisfaction.

On the other hand, integration team aspects, such as interpersonal relationships that promote cooperation and collaboration among agents in teamwork, are also experienced in the CCU context. Consequently, this facilitates the care quality and safety to patients.

Regarding the consequences, negative references for the professional/team predominated, mainly referring to professional dissatisfaction, feeling of inferiority in relation to other colleagues, frustration, discouragement, and stress, among others, which cause damage to agents and to the work carried out. Although there were more negative consequences for the professional/team, patients also suffer from these effects, especially the negative ones.

The results shown are coherent with the daily health service, still characterized by the professional training based on the clinical care model reinforced by the functional method of work organization. Such issues strengthen the segmentation of knowledge and actions; compromise collaborative practices and professional interactions; and limit multiprofessional teamwork. In addition, the fact that the CCU is a closed sector does not contribute to an effective interaction in the context of collaborative practices among agents and the coordination of their knowledge and actions.

It also can be observed that there is a lack of linear thinking of the data, since besides the situations and consequences being predominantly negative, behaviors follow another logic as predominantly positive.

It is important to mention this ambiguity in the results, since on one side there is a predominance of situations with negative references and negative consequences, but on the other side there are positive references in relating to other agents, indicating that, even dealing with such situations, there is personal investment for developing positive attitudes that facilitate the relationship among them, which in turn favors teamwork. However, regardless of the professionals' performance, negative consequences predominate, especially for the professional/team.

This shows a dialectic nature, although legitimate on the reports, and reflects the complexity that traverses teamwork, as well as the interpersonal and social relationships in health care service. Positive behaviors underline the attitudes toward commitment shown by the professionals trying to get the job done, despite various difficulties.

In order to carry out teamwork, it is crucial that, besides the will and availability expressed by some agents in accomplishing it, organizational and managerial conditions are coherent and in line with the teamwork proposal, serving as a potential tool for reconstructing the way of doing things in health care. In this regard, personnel management needs to be in line with teamwork preconditions, preferably with the team integration modality.

In this sense, personnel management needs to carry out strategic actions for mitigating negative consequences. The question is: What has been done regarding this matter on their daily routine? A feasible solution could be having the personnel management making integrated decisions aimed at work relationships, guiding and supporting professionals, not limited only to the CCU setting, but also in a macroperspective of the hospital as a whole.

It is important to emphasize that, based on the results, the working process in this CCU, taking into account teamwork, is centered on the relationships among the agents, in a perspective that it is closer to personal affinities and less focused on common objectives for achieving the work process - health care.

\section{CONCLUSION}

The application of the critical incident technique in this study enabled to analyze teamwork in a CCU from the perspective of a multiprofessional team, identifying facilitating and hindering aspects for the referred work.

The results referring to situations/behaviors/consequences show that low collaboration among agents, inadequate management of agents, lack of commitment toward work, disrespect to hierarchy, professional dissatisfaction, and the feeling of professional depreciation hinder teamwork in health care. On the other hand, relationships among agents, based on collaboration and exchange of information among team colleagues, are aspects that facilitate teamwork in health care.

The working process components that most frequently emerged in the results were the agents and non-material tools (relationships among agents/collaboration). It became evident that teamwork in this CCU is centered on the relationships among agents, since the aspects that facilitate and hinder the referred work are predominantly turned toward the question of the relationship among professionals/collaboration/mutual assistance/communication. The results stand out for not revealing the elaboration of common objectives as a precondition for carrying out teamwork.

Based on the results, it is considered appropriate to conduct new studies for approaching not only the management of agents, but also the development and implementation of collaboration as a potential integrating tool among agents and their knowledge, in the context of comprehensive care, as well as qualification and professional training for working in CCUs.

There is an intention for carrying out an intervention project jointly with the professionals of this CCU with an 
aim at discussing, rethinking, and understanding the teamwork dynamics in this setting, as well as building collective strategies through qualified hearing for overcoming setbacks. Coordination along with the team is suggested, in an attempt to find paths to be taken, by themselves, so the working dynamics can become less excruciating, more integrated/collaborative, and lead to more positive consequences for the professional/team and the patient.

As limitations, it is important to note that data were collected at a time when the hospital management was being restructured. However, most professionals were available for participating in the study. Although the study was developed in the CCU of a public teaching hospital, and this could be viewed as a limitation, there are public teaching hospitals in the organizational and working context that are very similar and the results of this study have the potential for having its visibility and application broadened.

Despite its relevance, little progress has been made for understanding 'teamwork', especially in coronary care units, which can have an impact for changing the reality of health care services. In practice, there must be a way of understanding that teamwork goes beyond the elaboration of common goals among team members. Services should incorporate theoretical production and move forward building relationships among agents, in a more dialogical and collaborative way. This will require organizational changes, from flowcharts to discussion groups and further consideration on the topic, keeping in mind that teamwork needs to be included as more than a mere strategy, but also as a tool for healthcare work.

\section{RESUMO}

Objetivo: Identificar, junto à equipe multiprofissional, aspectos facilitadores e dificultadores do trabalho em equipe em Unidade Coronariana. Método: Estudo descritivo, com dados qualitativos e quantitativos, realizado em Unidade Coronariana/Hospital público. População constituída de profissionais atuantes na Unidade há, pelo menos, um ano. Excluídos os afastados do trabalho e os que não foram não localizados. Para a coleta de informações, utilizou-se da Técnica do Incidente Crítico por meio de entrevista semiestruturada Para a análise dos dados, utilizaram-se da Análise de Conteúdo e Técnica do Incidente Crítico. Resultados: Participaram 45 profissionais: 29 profissionais de enfermagem; 11 médicos; quatro fisioterapeutas e um psicólogo. Emergiram 49 situações (77,6\% com referências negativas); 385 comportamentos (54,2\% com referências positivas); e 182 consequências (71,9\% com referências negativas). Referências positivas facilitam o trabalho em equipe, e as negativas o dificultam. Relacionamento interprofissional colaborativo/comunicativo foi evidenciado como facilitador; baixa colaboração entre agentes/gerenciamento inadequado como dificultador. Conclusão: Apesar de predominarem situações e consequências negativas, ênfase em comportamentos positivos revela esforço dos agentes para vencer obstáculos e realizar trabalho em equipe.

\section{DESCRITORES}

Equipe de Assistência ao Paciente; Relações Interprofissionais; Hospitais; Equipe de Enfermagem.

\section{RESUMEN}

Objetivo: Identificar junto al equipo multiprofesional los aspectos facilitadores y dificultadores del trabajo en equipo en Unidad Coronaria. Método: Estudio descriptivo, con datos cualitativos y cuantitativos, llevado a cabo en Unidad Coronaria/Hospital público Población constituida de profesionales actuantes en la Unidad desde hace por lo menos un año. Excluidos los retirados del trabajo y los que no fueron ubicados. Para la recolección de informaciones, se utilizó la Técnica del Incidente Crítico mediante entrevista semiestructurada. Para el análisis de los datos, se utilizó el Análisis de Contenido y la Técnica del Incidente Crítico. Resultados: Participaron 45 profesionales: 29 profesionales de enfermería; 11 médicos; cuatro fisioterapeutas y un psicólogo. Surgieron 49 situaciones ( $77,6 \%$ con referencias negativas); 385 comportamientos (54,2\% con referencias positivas); y 182 consecuencias $(71,9 \%$ con referencias negativas). Las referencias positivas facilitan el trabajo en equipo y las negativas lo dificultan. La relación interprofesional colaborativa/ comunicativa fue evidenciada como facilitadora; la baja colaboración entre agentes/gestión inadecuada como dificultadora. Conclusión: A pesar de predominar las situaciones y consecuencias negativas, el énfasis en comportamientos positivos desvela el esfuerzo de los agentes por vences obstáculos y realizar trabajo en equipo.

\section{DESCRIPTORES}

Equipo de Atención al Paciente; Relaciones Interprofesionales; Hospitales; Grupo de Enfermería.

\section{REFERENCES}

1. Littike D, Sodré F. A arte do improviso: o processo de trabalho dos gestores de um Hospital Universitário Federal. Ciênc Saúde Coletiva. 2015;20(10):3051-62.

2. Silva SEM, Moreira MCN. Equipe de saúde: negociações e limites da autonomia, pertencimento e reconhecimento do outro. Ciênc Saúde Coletiva. 2015;20(10):3033-42.

3. Silva JC, Contim D, OhI RIB, Chavaglia SRR, Amaral SEM. Perception of the residents about their performance in the multidisciplinary residency program. Acta Paul Enferm [Internet]. 2015 [cited 2015 May 12];28(2):132-8. Available from: http://www.scielo.br/pdf/ape/ v28n2/en_1982-0194-ape-28-02-0132.pdf

4. Morgan S, Pullon S, McKinlay E. Observation of interprofessional collaborative practice in primary care teams: an integrative literature review. Int J Nurs Stud. 2015;52(7):1217-30.

5. Peduzzi M. Equipe multiprofissional de saúde: conceito e tipologia. Rev Saúde Pública. 2001;35(1):103-9. 
6. Rissardo LK, Carreira L. Organization of healthcare and assistance to the elderly indigenous population: synergies and particularities of the professional context. Rev Esc Enferm USP. 2014;48(1):72-9.

7. Flanagan JC. A Técnica do incidente crítico. Arq Bras Psicol. 1973;25(2):99-141.

8. Dela Coleta JA, Dela Coleta MF. A técnica dos incidentes críticos: 30 anos de utilização no Brasil na psicologia, administração, saúde e educação. Taubaté: Cabral; 2004.

9. Dela Coleta JA. A técnica dos incidentes críticos: aplicações e resultados. Arq Bras Psicol Aplic. 1974;26(2):35-58.

10. Gonçalves RBM. Práticas de saúde: processos de trabalho e necessidades. São Paulo: CEFOR; 1992.

11. Polit DF, Beck CT, Hungler BP. Fundamentos de pesquisa em enfermagem: métodos, avaliação e utilização. $7^{\text {a }}$ ed. Porto Alegre: Artmed; 2011.

12. Bardin L. Análise de conteúdo. Lisboa: Edições 70; 2011.

13. Weinberg DB, Cooney-Miner D, Perloff JN, Babington L, Avgar AC. Building collaborative capacity: promoting interdisciplinary teamwork in the absence of formal teams. Med Care. 2011;49(8):716-23.

14. Carvalho PA, Göttems LBD, Pires MRG, Oliveira MLC. Safety culture in the operating room of a public hospital in the perception of healthcare professionals. Rev Latino Am Enfermagem. 2015;23(6):1041-8.

15. Farrel K, Payne C, Heye M. Integrating interprofessional collaboration skills into the advanced practice registered nurse socialization process. J Prof Nurs. 2015;31(1):5-10.

16. Rossler KL, Kimble LP. Capturing readiness to learn and collaboration as explored with an interprofessional simulation scenario: a mixedmethods research study. Nurse Educ Today. 2016;36: 348-53.

17. Alexanian JA, Kitto S, Rak KJ, Reeves S. Beyond the team: understanding interprofessional work in two North American ICUs. Crit Care Med. 2015;43(9):1880-6.

18. Manias E. The concept of teamwork does not fully explain how interprofessional work occurs in intensive care. Aust Crit Care. 2015; 28(4):235-7.

19. Rocha FLR, Marziale MHP, Carvalho MC, Cardeal SF, Campos MCT. The organizational culture of a Brazilian public hospital. Rev EsC Enferm USP. 2014;48(2):308-14.

20. Matuda CG, Aguiar DML, Frazão P. Cooperação interprofissional e a reforma sanitária no Brasil: implicações para o modelo de atenção à saúde. Saúde Soc. 2013;22(1):173-86.

21. Lancaster G, Kolakowsky-Hayner S, Kovacich J, Greer-Williams N. Interdisciplinary communication and collaboration among physicians, nurses, and unlicensed assistive personnel. J Nurs Scholarsh. 2015;47(3):275-84.

22. Silva AM, SÁ MC, Miranda L. Entre "feudos" e cogestão: paradoxos da autonomia em uma experiência de democratização da gestão no âmbito hospitalar. Ciênc Saúde Coletiva. 2015;20(10):3063-72.

23. Rosado IVM, Russo GHA, Maia EMC. Produzir saúde suscita adoecimento? As contradições do trabalho em hospitais públicos de urgência e emergência. Ciênc Saúde Coletiva. 2015;20(10):3021-32.

24. Valentine MA, Nembhard IM, Edmondson AC. Measuring teamwork in health care settings: a review of survey instruments. Medical Care. 2015; 53(4):e16-e30.

25. Tubbesing G, Chen FM. Insights from exemplar practices on achieving organizational structures in primary care. J Am Board Farm Med. 2015;28(2):190-4.

26. Deering S, Johnston LC, Colacchio K. Multidisciplinary teamwork and communication training. Semin Perinatol. 2011;35(2):89-96.

27. Mundt MP, Agneessens F, Tuan WJ, Zakletskaia LI, Kamnetz SA, Gilchrist VJ. Primary care team communication networks, team climate, quality of care, and medical costs for patients with diabetes: a cross-sectional study. Int J Nurs Stud. 2016; 58:1-11.

28. Longpré C, Dubois CA. Implementation of integrated services networks in Quebec and nursing practice transformation: convergence or divergence? BMC Health Serv Res. 2015;15:84.

29. Yang JG, Zhang J. Improving the postoperative handover process in the intensive care unit of a tertiary teaching hospital. J Clin Nurs. 2016;25(7-8):1062-72. 